

Original Research Article

\title{
Integrative governance for ecological public health: An analysis of 'Food Policy for Canada' (2015-2019)
}

\author{
Peter Andrée*, Patricia Ballamingie, Mary Coulas \\ Carleton University
}

\begin{abstract}
Normatively grounded in the ecological public health paradigm, this paper speaks to the role of public policy in addressing food and nutrition-related health challenges through a critical analysis of the 2019 Food Policy for Canada (FPC). We draw on primary data gathered through a SSHRC-funded Partnership Grant, Food: Locally Embedded, Globally Engaged (FLEdGE). Qualitative research methods include interviews with key stakeholders and policy makers, critical review of national food policy consultation documents, participant observation in government-, industry- and civil society-led conversations about the food policy, as well as an investigation of stakeholder responses to the FPC announcements of 2019. Our analysis focuses on how Canada's new food policy: adopts an integrative, pan-Canadian approach; explicitly connects health and environmental dimensions of food; augments food security in a systematic way; addresses unique food security and health issues facing Indigenous Peoples; improves the health of food environments, such as those in Canada's schools; and meaningfully includes relevant stakeholders in food system governance. Against these expectations, we assert that the Food Policy for Canada does not yet provide an integrative, systems-based approach to addressing food and nutrition-related health issues consistent with the ecological public health approach, despite significant progress made. We conclude by proposing a research agenda for tracking Canada's food policy implementation and development going forward.
\end{abstract}

Keywords: Food policy; ecological public health; Food Policy for Canada

*Corresponding author: peter.andree@carleton.ca

DOI: $10.15353 / \mathrm{cfs}-\mathrm{rcea} . \mathrm{v} 8 \mathrm{i} 2.450$

ISSN: 2292-3071 


\section{Introduction}

This paper speaks to the role of public policy in addressing food and nutrition-related health challenges through an analysis of the newly established Food Policy for Canada (FPC). While the policy announced by the Minister of Agriculture in June 2019 (GoC 2019c) remains in its early stages of implementation, this paper examines the development of Canada's national food policy since the Trudeau government initiated its creation in 2015.

This work emerges out of active collaboration with Food Secure Canada and other civil society organizations that are part of the Food: Locally Embedded, Globally Engaged (FLEdGE) research network based at Wilfrid Laurier University. Our node at Carleton University took the lead on research related to the national food policy shortly after it was announced in late 2015 . This research seeks to inform three key FLEdGE research themes: integration across multiple political jurisdictions and sectors; the tensions, compromises and opportunities inherent in the scaling up and out of sustainable food system initiatives; and the development of appropriate, innovative governance structures and institutions to support the development of sustainable regional food systems. FLEdGE partners work broadly to advance six 'good food' principles (see FLEdGE, 2016). While this research speaks to each of the six in some way, it touches most directly on the following principle: "We need good food policy that involves cross-cultural collaboration, all levels of government, and reflects the needs of people and their communities" (FLEdGE, 2016, Para 7). This paper is also informed by our engagement as researchers with the ad hoc Working Group on Food Policy Governance (2017a; 2017b), which included a diverse group of actors from academia, industry, farm groups, and civil society. ${ }^{1}$ Methodologically, it draws on qualitative data obtained through a mixed methods approach, including fifty-nine interviews with key stakeholders and policy makers between March 2017 and October 2020², document analysis of food policy efforts in Canada, participant observation in government, industry and civil-society led conversations about food policy, as well as an investigation of stakeholder responses to the FPC announcements of 2019. Informed by discourse analysis (Foucault, 1991), institutionalism (Skogstad, 2012), and political economic analysis (Andrée, 2007), this work is best characterized as critical policy analysis, which emphasizes the contingency of policy development and implementation (Mulderrig et al., 2019). Critical policy studies look beyond a policy text to understand the social and political interests, values, and normative assumptions that shape policy processes and outcomes (Fischer et al., 2015).

This article is organized into four sections. First, we introduce our conceptual framework - a joined-up, integrative approach to ecological public health, translated to the Canadian context. Second, we draw on recent food policy literature to identify six analytical themes.

\footnotetext{
${ }^{1}$ For more details on who participated in the ad hoc Working Group on Food Policy Governance, see: https://arrellfoodinstitute.ca/policy-council/

${ }^{2}$ The following is a breakdown of interviews completed: 23 State, 6 industry, 23 civil society, 7 academic.
} 
Originally organized as recommendations for government, each thematic section now includes questions we bring to our analysis of the FPC. Third, we critically examine specific aspects of the policy announced in 2019, including the newly funded infrastructure programs, national school food program announcement, and new governance mechanisms. This evidence allows us to speculate on how this policy responds to food and nutrition-related health issues in a way that is aligned with the ecological public health paradigm. To conclude, we delineate a research moving forward.

\section{Conceptual approach}

This research is situated within a global movement to build evidence-based, joined-up food policies intended to address food and nutrition-related health challenges, informed by the paradigm of ecological public health (Rideout et al., 2007). ${ }^{3}$ We define food and nutrition-related health challenges broadly as the myriad influences, including socio-economic inequalities and environmental factors, that affect the health of people living in Canada. These issues include diet-related chronic diseases like cardio-vascular disease, obesity ${ }^{4}$, diabetes and diet-related cancers, as well as a wider range of health issues related to how our food systems work, such as environmental exposure to dangerous chemicals.

Collectively, nutrition-related diseases pose a growing public health risk in Canada. For example, in 2012-2015, nearly 1 in 4 Canadians over twenty years of age were diagnosed with hypertension (a serious risk condition for heart disease, stroke and dementia) - exacerbated by excess body weight, and immoderate consumption of alcohol and salt (Statistics Canada, 2019). The Government of Canada (2021c) also describes a steady and dramatic rise in diabetes, since 2000 with type 2 diabetes linked closely to diet as well as genetics and age. Such nutritionrelated chronic diseases correlate with behavioural factors like inactivity, but they are also influenced by food access and quality, socio-economic status, social supports, and built environment, among other factors (Tarasuk et al., 2010). Health issues related to how our food system functions are less readily quantified, but remain nonetheless. Examples include exposure to toxic pesticides (by consumers and agricultural workers), declining food access resulting from global environmental change, as well as the unique health issues facing food system workers like repetitive stress injuries (Johnstone, interview, April 23, 2020; Schnitter and Berry, 2019).

\footnotetext{
${ }^{3}$ Notably, we did not frame this research through the ecological public health paradigm at the outset. Rather, this framing emerged over the course of presenting our work at conferences and preparing this paper because of how it clearly encapsulates so many of the expectations coming from academics, civil society, and government actors alike for what a national food policy in Canada could and should achieve.

${ }^{4}$ Obesity is widely referred to in the health and nutritional literature but remains a problematic term in the ways it pathologizes certain body types, which in turn has racialized implications. In the absence of a better way to allude to the adverse health implications of excess weight, we follow the British Psychological Society in referring to "people living with obesity" to mitigate stigma, though we agree with Pausé (2019) that the best approach would be to ask individuals their preference.
} 
Food and nutrition-related health issues are not experienced equally by everyone. For every issue, there are groups who are disproportionately affected because of their race, socioeconomic status, location and occupation, among other factors. In the case of health issues related to food insecurity, for example, Melana Roberts (2020) of Food Secure Canada asserts: "In Canada, more than 4 million people struggle with the burden of food insecurity, with a disproportionate number of Black, Indigenous and racialized Canadians identifying as food insecure as a result of enduring racialized income inequality." She further explains that Black Canadians experience food insecurity 3.5 times more than White Canadians, leading to a host of health disparities. As a second example, rates of people living with obesity are significantly higher for off-reserve First Nations, Métis and Inuit than for non-Indigenous populations (GoC, 2013). Further, the food and nutrition-related health challenges of people who rely on storebought food in cities differ significantly from those who rely on hunted game in rapidly changing remote Northern environments. And, even within major cities, specific communities may have differential access to healthy and unhealthy foods depending on where they live (Mah et al., 2016). In response to such differences, public policy must target vulnerable populations to mitigate health and nutritional disparities. Seeking to address nutrition-related health inequities involves "assessing and addressing social, economic and spatial disparities in the food environment; examining how food environment disparities affect different populations disproportionately; promoting a fair distribution of resources; and enabling individual capacities" (Mah et al., 2016, p.66).

Lang, Barling \& Caraher (2009) advocate for an integrated approach to addressing food and nutrition-related health issues. They argue for food policies at multiple, interrelated, levels of governance based on the fundamental principles of ecological public health. This approach brings insights from complexity theory and systems dynamics, to encourage the open debate and pursuit of social values, and embraces interdisciplinarity as well as multi-actor approaches to address health challenges (Lang \& Rayner, 2012).

Our analysis here is normatively grounded in this ecological public health paradigm. While we recognize Canada's new food policy is not explicitly rooted in this paradigm, we believe a critique informed by this perspective is reasonable given the breadth of the new policy's vision, which states: "All people in Canada are able to access a sufficient amount of safe, nutritious, and culturally diverse food. Canada's food system is resilient and innovative, sustains our environment and supports our economy" (GoC, 2019e, p.5). The policy's six principles, outlined in our analysis below, also imply a desired level of integration across the government's food-related policies and strategies consistent with this approach.

What does an ecological public health critique entail? It means situating food and nutrition-related health issues within a multi-scalar analysis of the food system and considering how public policy can support efforts at each of these scales to stimulate health-promoting food environments. 
Figure 1 delineates key scalar factors influencing food choices - nested from the individual level to the socio-cultural and community environments, to the agricultural, industry and market conditions, to governmental programs and supports, to the global geopolitical, environmental and economic context. ${ }^{5}$ First, food choices are shaped by personal preferences and dietary habits, though this should not mean the onus of responsibility rests entirely with the individual. In fact, this diagram clearly illustrates that the individual is nested within a food system that impacts agency at every scale. This model recognizes the importance of broader structural and societal constraints shaping food choices. Individuals are significantly differentiated in their ability to access healthful and nutritious food, or to work in less risky occupations, notably by income, education, nutritional knowledge, skills, and health status. Second, food environments matter. This includes neighborhood retail and restaurant options (or lack thereof), workplace and school offerings, as well as how food is marketed. Third, how we produce our food, and what governments choose to subsidize, directly impacts nutritional quality, food safety, ecological integrity, and for all these reasons, human health. Fourth, government departments at various scales (agriculture, community and economic development, public health, trade, and foreign affairs) are all implicated in problems like food insecurity and chronic health challenges. Finally, global forces such as commodity prices, climate and scientific developments all shape what is possible (and not) at each of the other levels. ${ }^{6}$

\footnotetext{
${ }^{5}$ For a fuller discussion of how these factors interrelate, see Mozzaffarian et al., 2018.

${ }^{6}$ One limitation we see to this diagram is that it could tease out in more detail the biophysical contexts, from the local to the global, within which food choices get made. Such contexts include soil quality, nutrient cycles, and levels of toxic contaminants in specific environments, etc.
} 
Figure 1: Scalar factors impacting food choices

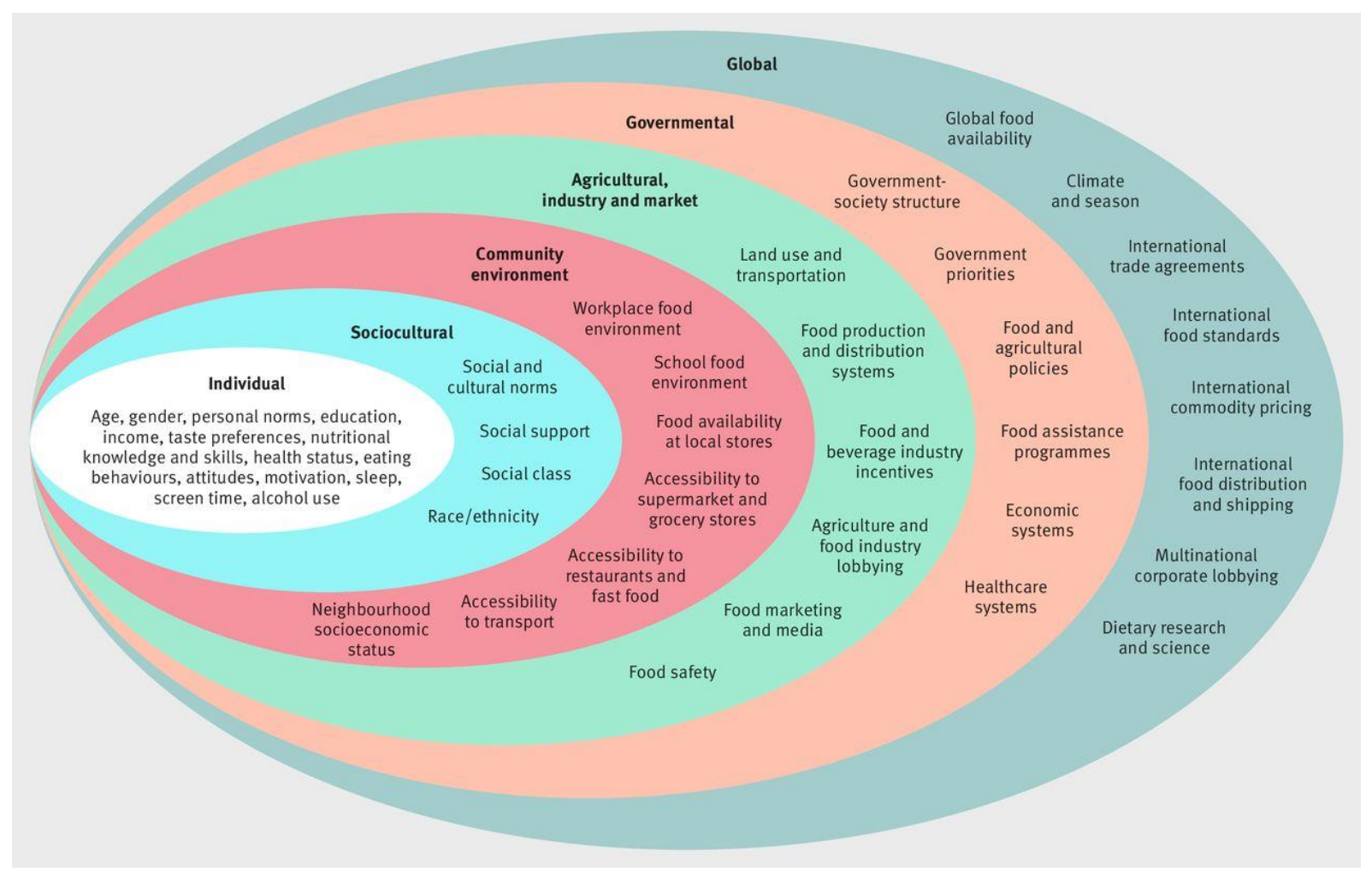

Source: Mozzaffarian et al., 2018

To bring an ecological public health approach to food policy means considering a wide variety of multilayered and interconnected sociocultural determinants and political economic factors-a feat which can only be accomplished through an integrative or joined-up (two terms we treat as synonymous in this paper) governance approach that remains mindful of these scalar connections. MacRae and Winfield (2016) characterize a "joined up food policy" as follows:

By joined-up food policy, we mean the coherent and comprehensive policy environment that links food system function and behaviour to the higher order goals of health promotion and environmental sustainability. A joined-up policy unites activities across all pertinent domains, scales, actors and jurisdictions. It employs a wide range of tools and governance structures to deliver these goals, including sub-policies, legislation, regulations, regulatory protocols and directives, programs, educational mechanisms, taxes or tax incentives, and changes to the loci of decision making. (p.141)

In Canada, as in every country, what a joined-up approach could look like depends on the administrative organization of the state, as well as the relationship among state, market actors and civil society. Canada is a federal country with thirteen provinces and territories. 
Under the Constitution Act, 1867, the provinces have the exclusive authority to govern in certain areas, such as health, natural resources, and education, while the federal government has authority over, for example, trade, commerce, and environment. These two levels of government also share jurisdiction in certain domains, such as agriculture. Since 1867, courts have added nuance to questions of jurisdiction related to many areas of food system governance, sometimes granting more power to the provinces (such as over environmental protection), and sometimes articulating a more "expansive view of federal power" (Richardson \& Lambek, 2018). Unlike provinces, the territories (Northwest Territories, Nunavut and Yukon) have no constitutional powers of their own but receive legislative authority from the federal government. Current powers exercised by territories include education, social services, and health (GoC, 2020a). Finally, as of the 1970s, when the first of Canada's modern treaties was negotiated, twenty-five Indigenous communities now exert self-government (GoC, 2020b). As with the territories, Indigenous self-government typically involves control over education, social services and health care institutions (GoC, 2020b).

Over the last 150 years, the various levels of government have each developed myriad laws, policies, and regulations governing aspects of the food systems that affect Canadians' health. Directly governing food within federal legislation, for example, Canada has a Food and Drug Act (1920, 1985), the Safe Food for Canadians Act (2012), the Seeds Act and the Pest Control Products Act (2002), to name just a few. Canada also has cost shared federal-provincialterritorial policy frameworks such as the Canadian Agri-Food Policy Framework. Then, there are federally funded programs that shape food systems outcomes such as Nutrition North, a program which subsidizes eligible food retailers in select remote communities. Canada also has national strategies developed in consultation with provinces and territories, such as its Poverty Reduction Strategy (2018) and National Housing Strategy Act (2019) as well as federal dietary guidelines found in the Healthy Eating Strategy (2016) and Canada Food Guide (2019). Meanwhile provincial, municipal and territorial laws and policies, including recent provincial food policy efforts in Québec and British Columbia, as well as a raft of recent municipal food charters, combined with the effect of Comprehensive Land Claim Agreements negotiated between the Crown and Indigenous governments (some of which have resulted in Indigenous selfgovernment) all add layers of complexity to the policy landscape shaping food systems in Canada (Martorell \& Andrée, 2018). The result is a patchwork approach to food-related law and policy that lacks coherence in relation to a common vision of a healthy and sustainable food system. Needed is a more integrated food policy approach, or what we have previously termed a "pan-Canadian" (Andrée et al., 2018) approach, one which requires coordination across multiple federal policy domains (finance, health, environment, fisheries, agriculture, etc.), and brings greater coordination across levels of government as well as with civil society and industry actors. 
Pesticides provide an illustrative example of why an integrative approach is necessary. At the federal level, the Pest Control Products Act, administered by Health Canada, ultimately reviews and regulates pesticide use, resulting in decisions intended to safeguard consumer health (Health Canada's Food Directorate and the Canadian Food Inspection Agency), but also impacting farmer livelihoods (the purview of Agriculture and Agri-Food Canada and provincial agriculture departments), non-target organisms and ecosystem health (the realm of Environment and Climate Change Canada), and even agricultural exports (Global Affairs Canada). Moreover, risk assessment is an inherently normative concept, and civil society proponents have long flagged the unknown, adverse impacts of cumulative, synergistic exposure to pesticide residues for consumers, not to mention spray drift for farm workers and adjacent communities (see CBAN, 2020; PAN, 2020). Thus, critics argue the health and environmental lenses are not foregrounded strongly enough, alongside other economic considerations. ${ }^{7}$ Navigating this one issue related to food systems governance requires a more integrative approach that privileges a shared vision of safe and healthy food system, while recognizing distinct but overlapping jurisdictions, competing and sometimes contradictory priorities, and interconnected issues, across various scales and regions.

Moving forward, we evaluate FPC through the ecological public health paradigm. Given that this is a piece of federal government policy, this analysis pays due attention to jurisdictional considerations. Alongside our ad hoc Working Group on Food Policy Governance (2017a) partners, we see the federal government's role in an integrative national food policy as that of: a leader in developing a holistic approach across departments and agencies; an innovator in designing new cross-cutting policy solutions to long-standing issues like food insecurity; a partner in negotiating nation-to-nation policy with Canada's Indigenous (First Nation, Métis and Inuit) governments; a convener of food system governance coordination efforts with other levels of government, industry and civil society; and, a (co-)funder of resultant strategies and action plans. In the following section, we further elucidate this vision before unpacking how the FPC measures up.

\section{Analytical themes}

First prepared as its own research output prior to the announcement of the food policy in 2019, this section sets the agenda for our analysis. It develops the ideal of ecological public health by drawing on recent academic literature and some of our primary data to suggest how Canada might address food and nutrition-related health issues in this federal nation with diverse communities and needs.

\footnotetext{
${ }^{7}$ Martorell \& Abergel (2018) offer a solid overview of how Québec navigates the precautionary approach, multifunctionality and subsidiarity in its agricultural policy.
} 
This material is organized under six overlapping themes, each of which results in questions to ask of the FPC: Integrative Governance; Ecological Sustainability for Health; Food Security and Right to Food; Healthy Food Environments; Indigenous Food Self-Determination; as well as Meaningful Stakeholder and Public Engagement.

\section{Integrative governance}

Central to the ecological public health paradigm is the goal of integrative governance not only among federal government departments but also with other levels of government, industry and civil society. For example, at a national level, the institutional apparatus administering Norway's Nutrition and Food Policy (originally created in 1936 and revamped in 1975) provides a useful model for what this can look like (Blueprint for a National Food Strategy, 2017). At the ministerial level in Norway, two formal bodies coordinate the implementation of the country's policy across government departments: the National Food Control Authority (a centralized, coordinating agency) and the National Nutrition Council, with the latter including nongovernmental voices to ensure multi-stakeholder input into government policy. Since 1975, the official nutrition and food policy White Papers produced by the National Nutrition Council "have been central political and strategic documents in the efforts to improve public health in Norway during the last thirty years" (Norum et al., 2005, p. 735).

To date, Canada has yet to realize an integrated approach to food policy at the national level, though some relevant examples exist at provincial, territorial and municipal levels (Martorell \& Andrée, 2018). Lack of integration may be partly explained by the way powerful industrial agricultural interests - some deeply opposed to change-dominate agri-food policy at the federal level (Andrée et al., 2018). Long-standing differences among food system stakeholders also mean there was no unified voice calling for change. However, under the promise of government action on food policy in 2015, many of these stakeholders found new ways of working together through the ad hoc Working Group on Food Policy Governance. Building on the spirit of collaboration evident in the ad hoc Working Group, we analyzed shared priorities among diverse stakeholders who were active on the food policy file in Canada in the 2010s and identified considerable consensus around six major substantive goals (Andrée et al., 2019). To meet these goals, we then laid out five recommendations related to food policy governance. Those recommendations can also be seen as criteria for considering the extent to which the FPC furthers integrative governance. To what extent does the FPC: further a panCanadian strategy (inclusive of all levels of government)?; set measurable targets and mechanisms to ensure accountability (recognizing there will invariably be regionally distinct, place-based ways to achieve such outcomes)?; enable the scaling up and out of tried-and-true initiatives from municipal, provincial and territorial levels?; involve ongoing stakeholder dialogue and problem-solving?; and ensure strong cross-departmental coordination at the federal level? 


\section{Ecological sustainability for health}

Academic discussions in Canada about what a joined-up food policy can do to further the complementarity of ecological sustainability and public health goals build on, and contribute to, the international literature on ecological public health. Lang (2009) argues that health and environmental sustainability require integrated thinking and food policy for both crisis-related solutions (short-term) and evolutionary prevention (long-term). Lang and Barling (2012) assert that this shift to multi-temporal thinking requires a conceptualization of food and health as integrally connected to and reliant upon ecosystems. However, the International Panel of Experts on Sustainable Food Systems (IPES-Food) (2016) points out that industrial agriculture will remain entrenched if systems are measured only in terms of a small set of production and economic indicators, and not in terms of their overall social, environmental and economic impacts. This assessment appears to characterize where Canada is starting from as it embarks upon a more integrative food policy. How food is produced significantly determines ecological impact regarding climate, biodiversity, water quality, soil, and efficient use of scarce resources. Canada's agricultural system is a source of $8.4 \%$ of the country's greenhouse gas emissions (GoC, 2021b), with about half of this related to livestock production. Meanwhile $58 \%$ of food produced in Canada is never eaten, being considered either food loss or waste (Gooch et al., 2019). Bacon et al. (2019) argue that Canada's food policy project aligns with agro-industrial export models focused on economic growth. Instead, productivity gains must be evaluated alongside critical environmental indicators — an approach made possible through the ecological public health paradigm.

Despite these challenges and critiques, Canada already has functional food production systems more consistent with the ecological public health paradigm. For example, Tia Loftsgard, executive director of Canada Organic Trade Association, argues that Canada's organic food sector offers a viable model for food security and sustainability, and its profitability and growing exports suggest an assured future (Loftsgard, interview, May 13, 2020). And, in contrast to intensive livestock production (with its ecological costs), Canada's strong pulse sector, already supported by public sector investment, underpins a growing plant-based protein industry (Krutt, 2019). Finally, Canada has a growing suite of alternative and local food system initiatives, many developed to mitigate impacts of the large-scale, export-oriented agricultural system. However, these smaller-scale production systems often suffer because regulations and policies have been designed for larger-scale systems. To encourage a shift towards more sustainable forms of food production that are also health-promoting, this review suggests we examine the extent to which the FPC actively aligns environmental, economic and health goals, along with the programs designed to help achieve them. Does it explicitly connect ecological sustainability and health by, for example, encouraging forms of food production and distribution that address pressing issues like climate change and the rise in chronic nutrition-related disease? 


\section{Food security and right to food}

Dachner and Tarasuk (2018) argue that a national food policy offers Canada an opportunity to address food insecurity and prevalent nutrition-related health issues because it can simultaneously promote healthy consumption habits and safe food practices. Canada is one the largest food producers and wealthiest countries in the world. However, four million people living in Canada (12.7\% of households) (PROOF, 2016b), among them 1.15 million children, have trouble meeting their food needs (PROOF, 2016a). The resultant food insecurity, as Tarasuk and Mitchell (2018) explain, "takes a serious toll on individuals' health and well-being, and it places a significant burden on our health care system" (p. 3). The authors identify a host of public health challenges exacerbated by food insecurity, from "mood and anxiety disorders, arthritis, asthma, back problems, and diabetes" to "higher mortality rates" $(2018$, p. 6). This problem is more prevalent in northern and remote communities, such as Nunavut, where two-thirds of children remain food insecure (PROOF, 2016a). Food insecurity is closely intertwined with poverty and inadequate housing. Choosing between buying food and paying for housing can make it impossible for segments of the population to make autonomous food choices or meet basic dietary needs. Inconsistent food and nutritional literacy also impacts food choices, dietary habits and overall health (Howard \& Brichta, 2013).

In recent years, many Canadian researchers attribute food insecurity primarily to income insecurity (Dachner \& Tarasuk, 2018). However, the logic of their analysis, which points towards the potential role of a basic income guarantee, is easily lost in partisan debates over the role of the individual versus that of the state. McIntyre et al. (2018) argue that such partisan responses render an addressable problem seemingly intractable.

One way to confront the issue of food insecurity at an institutional level is to address it as a human right. Various prominent individuals and groups, including the UN Special Rapporteur on the Right to Food, Olivier de Schutter (2012), have noted that the federal government of Canada has a legal obligation to ensure the full realization of the right to food for all those living in Canada as a State Party to the International Covenant on Economic, Social and Cultural Rights, but that Canada does not yet provide legal or constitutional protection of the right to food. After his visit in 2012, De Schutter concluded that Canada would benefit from a national right to food strategy to better understand who is hungry, food insecure and malnourished. Within this approach, better evidence-based research for the realization of the right to food would occur and clear allocation of responsibilities across different levels of government would follow. Riches and Silvasti (2014) and Rideout et al. (2007) argue the right to food framework addresses the limitations of Canada's now dominant and normalized approach to food insecurity - the charitable model reliant on foodbanks. The latter effectively allows governments to hide their inaction (Jindra, 2016). 
In their submission to the FPC consultation process, the ad hoc Working Group on the Right to Food (2017) argue that this new policy provides an important opportunity to demonstrate Canada's commitment to its human rights obligations. ${ }^{8}$ Thus, we ask critically: To what extent does the FPC augment food security in a systematic way (beyond charity-invoking the Right to Food), by making structural connections to poverty and income security?

\section{Healthy food environments}

There is a rich conversation in Canada about what an approach consistent with ecological public health entails when it comes to supporting healthier food environments at multiple levels of governance, and the role federal policy can play. Mah et al. (2018) advocate close attention to the conception, construction and implementation of food environments, including how people are exposed to food marketing, to help remedy issues of food insecurity, health, and nutrition. Food environment interventions can be of a diverse nature, and often start at the community level, though they can be facilitated by policy at all levels of government. They include encouraging healthier options at corner stores, to supporting community kitchens, freezers and gardens (Andrée et al. 2016). Mah et al. (2016) note that "many interventions adopt goals such as community development, economic development or ecological sustainability alongside health aims," with entrepreneurialism as a form of social change-making. Further, understanding children's food environments, such as the food children eat while at school, elucidates which environments have effects on consumption habits and diets (Engler-Stringer et al., 2014). Government and public health have the potential to take this evidence and shift policy accordingly. However, Nelson et al. (2018) caution that a national food policy should avoid a framework based on assumed 'best practices' because it can undermine the reality that food issues are contextual; as a result, 'good practices' is used more widely. Place-based approaches to preventing and solving food issues are best understood by those experiencing them.

Canada is the only member country of the Organization for Economic Cooperation and Development (OECD) without a national school meal program (Hernandez et al. 2018). The proposed national school food program is thus an opportune food environment to encourage healthy eating and improve individual, household and community nutritional knowledge. Hernandez et al. (2018) argue that "school food programs have been shown to benefit health and dietary behaviour and critical food literacy skills (learning, culture, and social norms) that support local agriculture and promote sustainable food systems" (p. 208).

\footnotetext{
${ }^{8}$ The Ad Hoc Working Group on the Right to Food included representatives from community and national civil society organizations and academics with expertise in law, social work, and environmental resources sustainability. For a full list of working group participants and the objectives of this group see their submission, Ensuring the Human Right to Food Through A Food Policy for Canada, to the Government of Canada in 2017.
} 
Such an approach complements current conversations of integrating health, nutrition and environment into education (Bundy et al., 2012). In principle, then, a national approach to school food could be designed to be contextually-appropriate, responding to Nelson et al.'s (2018) concerns noted above. School food provides a domain in which nation-wide standards could be set, while being carried out in a decentralized manner through multi-level coordination of national, provincial and local communities (Andrée et al., 2019). In this regard, we must ask: How does the FPC help to create or maintain healthy food environments? How might it further a holistic approach to school food nationally, while ensuring programs are appropriate to diverse community contexts?

\section{Indigenous food self-determination}

An ecological public health approach means taking health equity seriously. Indigenous Peoples are among the most vulnerable in Canada to food and nutrition-related health disparities due to historical and ongoing threats to land, culture and linguistic heritage which ultimately destabilize identity and self-determination (ITK, 2017; Kuhnlein, 2013; Levi, 2017; NWAC, 2018). As a result, Indigenous proponents argue that effective mitigation of health issues prevalent in their communities closely interconnects with the advancement of food security, human rights, Indigenous food sovereignty ${ }^{9}$, and greater self-determination (Coté; 2016; NWAC, 2018).

Many have argued that stronger Indigenous participation in the development and implementation of a national food policy should better attend to Indigenous priorities (e.g. Luppens \& Power, 2018). However, there are mixed views on what such participation signals. Kepkiewicz \& Rotz (2018) have expressed concern that a "national" effort is "rooted in colonial assumptions," that problematize reconciliation efforts ${ }^{10}$ (p. 14). They further argue the (im)possibility of a national food policy that takes Indigenous food sovereignty seriously; in their view, scaling food policy to the national level continues to impose the Canadian state's power over Indigenous Peoples and their diverse means of food provision which are unique to place and space. Further, some of the dominant assumptions informing research and health promotion activities targeting Indigenous peoples prove inconsistent with evidence produced by Indigenous Peoples themselves (Adelson, 2005; Levkoe \& Blay-Palmer, 2018). When Andrée et al. (2019) examine the configuration of state and civil society actors seeking food policy influence, they note that not all voices are at the FPC table, and Indigenous peoples remain notably underrepresented.

\footnotetext{
${ }^{9}$ The Indigenous position statements we refer to are not all framed around the concept of Food Sovereignty, hence we call this theme "Indigenous Food Self-Determination."

${ }^{10}$ The fact that the Truth and Reconciliation Commission's Calls to Action fail to make explicit reference to food is perhaps telling.
} 
Collectively, these observations lead us to ask: How does the FPC engage with the unique food security and health issues faced by Indigenous Peoples? How does it serve to strengthens Indigenous food self-determination? And, is it designed respectfully and equitably with appropriate Indigenous governance bodies?

\section{Meaningful stakeholder and public engagement}

The ecological public health paradigm recognizes the important role that non-state actors can and should play in the achievement of integrative food policy goals (Lang and Rayner, 2012). Decisions about what fishers and farmers harvest, what the food industry produces, and how supply chains operate, all have ramifications for the health of those who eat this food as well as those exposed to it in their workplaces and communities. This paradigm also foregrounds the value of public engagement and debate over how the food system operates, and the outcomes it achieves (Lang and Rayner, 2012). The idea of public and stakeholder engagement in policy setting and implementation have been central to the food policy conversation in Canada over the last decade. La Via Campesina's 2003 call for food sovereignty, defined as "the people's... right to define their agricultural and food policy" was a critical source of inspiration for the People's Food Policy (PFP) project (2007-2011) (Food Secure Canada, n.d.; Martin \& Andrée, 2017). Subsequent food strategy documents by the Canadian Federation of Agriculture, Canadian AgriFood Policy Institute, the Conference Board of Canada and national Indigenous organizations each contributed to the conversation provoked by the PFP. Commonalities among those diverse stakeholder positions, along with the dogged advocacy of Food Secure Canada, set the stage for Trudeau's national food policy announcement of 2015 (Andrée et al., 2019).

As noted above, we have been actively involved in an informal working group of stakeholders advising government on options related to food policy governance. Over sixty industry, civil society, and philanthropic organizations supported the ad hoc Working Group on Food Policy Governance's proposal to the federal government (ad hoc Working Group 2017a and 2017b). It called on government to create a "National Food Policy Council, a new independent multi-stakeholder body.... to provide consistent monitoring, well-researched advice, and broad stakeholder support for a FPC" (ad hoc Working Group 2017a, p.4). The group envisioned such a council to facilitate two critical ends: coordination of policies and programming within and between departments and levels of government; and an inclusive approach to policymaking that actively considers the needs of diverse stakeholders by undertaking public engagement to inform its work.

Civil society councils have been developed in other countries to advise on integrated food policy efforts, and at other levels of governance. Brazil, as one example, has benefitted from a National Food and Nutrition Plan since 1999 (Ministry of Health of Brazil, 2013). 
Its Unified Health System aligned food policy across governmental levels and silos, with active civil society co-governance (Leão \& Maluf, 2013) to translate proposals into policy through the National Council on Food and Nutrition Security (CONSEA). During a Food Secure Canada panel on Food Policy Governance, Elisabetta Recine (2018), CONSEA President, described the body as "an institutional space that articulates across government and civil society to advise the President of the Republic." She cited Brazil's Art 2 Law 11.346 (2006): "The human right to adequate food makes all the difference!" and further stressed that this is: "Not only about food justice, but also social justice". ${ }^{11}$ The Civil Society and Indigenous People's Mechanism (CSM) to the UN FAO's Committee on Food Security (CFS) represents a similar model. Among the advantages of this mechanism within the CFS, Anderson (2019) argues that it allows those suffering from hunger and food insecurity to be heard from directly and to participate in defining solutions. Further, civil society actors play an important "watchdog" function. Ultimately, the CSM gives the CFS greater legitimacy and accountability to those who are most impacted by decisions (Anderson, 2019).

Because of the wide reach of the FPC, an advisory mechanism that only includes civil society representation would likely prove an imperfect match. Finland offers an example of a true multi-stakeholder advisory body. Finnish nutrition policy is based on a "good monitoring system of nutrition and risk factors of chronic diseases, as well as active epidemiological research" (Pietinen et al., 2010: p. 901). As of the 1980s, the policy is guided by the Finnish Nutrition Council. The Minister of Agriculture and Forestry appoints its members, including representation from health, nutrition, food safety, research, health promotion, food production, trade, consumers and catering services (Roos et al., 2002). In 1989, the Council was allocated a small but high-powered secretariat, co-chaired by the Ministry of Social Affairs and Health (Milio, 1991; Roos et al., 2002). The Council issues nutritional recommendations, advises government, undertakes research, and generates reports on efforts by industry and other actors intended to improve diets. While this top-down approach is not fully consistent with an ecological public health paradigm, in our view, the Finnish Nutrition Council represents a starting point for working across silos, and with stakeholders, to enact a more integrative national policy.

Our three international examples (Norway, Brazil and Finland) not only exhibit diverse policy and governance interventions, but also embrace a cross-governmental approach involving key stakeholders. The greatest impact and legacy of food policy occurs when new institutional bodies are established.

\footnotetext{
${ }^{11}$ Despite its strong track record over the last twenty years, Brazil's right-wing president, Jair Bolsonaro, who took office on January 1, 2019, eliminated CONSEA, presumably due to its critical stance on agrochemical and advocacy for family farming. His government transferred food security to the Ministry of Citizenship. Recine (2018) views this as a significant setback for civil society and win for agribusiness. However, Congress defeated this Presidential decree and fully reactivated the organization as part of the National Law for Food and Nutrition Security. Nonetheless, the Bolsonaro regime poses an ongoing threat to human rights and social policy advances in Brazil.
} 
Norway's Inter-Ministerial Council, Finland's National Nutrition Council and Brazil's CONSEA are each institutional bodies formally incorporated into state mechanisms, thereby ensuring food policy is coordinated across relevant departments, with strong stakeholder buy-in. However, Canada's situation differs from each of these countries in notable ways: Canada is the world's fifth-largest agricultural exporter (CAFTA, 2021) while both Norway and Finland are high-cost producers whose agricultural policies tend to focus on maintaining a high degree of selfsufficiency (OECD, 2021). Of the three, Brazil is also a major agri-food exporter, but its food policy explicitly regulates the domestic sector rather than exports. Interestingly, despite significant efforts at an integrative and inclusive approach, these three countries' food-related policies remain divided into two distinct realms: agriculture (production and industry support) and health (consumption related to nutrition and diet), with distinct policy measures implemented in each realm. To date, we have found no comparator of a major agri-food exporting nation that has succeeded to bring these policy areas together in the way the ecological public health paradigm encourages, which thus raises the question of how Canada's FPC will ensure meaningful stakeholder and public engagement?

\section{Analysis of a food policy for Canada}

This section critically analyzes Canadian food policy developments vis-à-vis the themes and questions identified in each of the six sub-sections above, considering only aspects of the policy most relevant to addressing food and nutrition-related health issues. It focuses on the FPC initiatives announced in the March 2019 federal budget, which allocated \$134M in new cash investments over 5 years (GoC, 2019b), as well as the more detailed policy announced in June 2019 (GoC, 2019c). To understand the development of the government's position on certain issues, we refer to other steps in the policy process as appropriate, including the government's response (GoC, 2018a) to the food policy report of the House of Commons Standing Committee on Agriculture and Agri-Food (GoC, 2017b), and documents released during the FPC consultation process.

Having received a mandate from the Prime Minister to create a food policy in late 2015, the Minister responsible for AAFC called together an inter-departmental committee to work on the future policy. The government then conducted a public consultation process from May to October 2017. They gathered input through a wide range of means, including: approximately forty-five thousand online surveys; six regional engagement sessions (with a total of 352 participants) across Canada; a National Food Policy Summit in Ottawa with 291 participants; 100 written submissions; twenty-nine town hall meetings hosted by Members of Parliament; fourteen submitted briefs; fifty-two witnesses to the House of Commons Standing Committee on Agriculture and Agri-Food; twenty-eight community-led events; and four bilateral or self-led engagement by national Indigenous organizations (Government of Canada, 2018, pp. 5 and 37). 
The FPC that resulted from this activity can be parsed out into five main components: a vision statement (quoted verbatim above), six "priority outcomes", four "action areas" intended to "make progress on outcomes", six "principles to help guide.... work" (GoC 2019d, p. 5), and a short section on accountability and governance. It notes that specific, measurable targets for each of the priority outcomes will be developed by federal partners (as part of a "cross-government reporting framework" (GoC 2019d, p. 8) for accountability) with input from a new governance mechanism called the Canadian Food Policy Advisory Council. Details on relevant priority outcomes, action areas and the new governance mechanism are discussed below. Notably, the government's six principles represent a promising start to a food policy effort intended to address food and nutritional disparities.

Key elements of the six principles prove consistent with the ecological public health paradigm that informs our analysis. If taken seriously, they form a strong basis for integrated food policymaking. The principles are: 1) "Inclusion and Diversity" in food policy dialogue and decision-making, among other contexts; 2) "Reconciliation", which includes the recognition that First Nations, Inuit and Métis communities have distinct food systems that have been disrupted by Government policies, and highlights active support for "Indigenous food self-determination"; 3) "Collaboration" among governments, organizations, and Indigenous communities, among others, in a systemic approach to food system challenges; 4) "Innovation", including both technological and social (including community-based) innovation; 5) "Sustainability," including "support for the adoption of practices and technologies that contribute to clean air and water, soil health, biodiversity, sustainable use of resources (e.g. greenhouse gas emissions, energy, farm inputs, and water) and climate change mitigation and adaptation," and 6) "Evidence and Accountability", including developing indicators and making decisions on "best available data, knowledge and research, including traditional forms of knowledge." Each of these principles takes a clear position on issues that have vexed Canada's food system over the years, such as an overemphasis on industry voices informing agriculture and food-related policies, inadequate attention to Indigenous foodways and the inherent rights of Indigenous people to pursue them, an overemphasis on technological fixes to issues like food insecurity, inadequate attention to biodiversity protection and the constructive role that food systems can play in addressing climate change, and the need for evidence-based approaches to policy, even if that evidence goes against a country's perceived economic interests. However, the devil always lies in the details. Because a policy's programmatic and administrative structure is critical to what it can be expected to achieve, we begin our analysis with a focus on the FPC's promise to offer greater integration of policy and programming. 


\section{Integrative governance?}

The FPC mentions how "all orders of government, including many federal departments" have sought to address food systems issues, and specifically draws attention to "income support programs that reduce poverty, that can also reduce food insecurity" (GoC 2019d, p.3) — without truly defining government-wide goals around critical issues like food and income security. The lack of stronger intra-governmental coordination represents a missed opportunity, given how the What We Heard Report (GoC 2018b, p.29) spelled out the "need for policy and program coherence" among, for example, "the Healthy Eating Strategy, Canadian Food Inspection Agency labelling initiatives, the FPC, and other health and food regulations" as a "priority in all consultations and themes."

To bolster the point that greater intra-governmental coordination was indeed expected through this policy, recall that in all 2015 Mandate Letters to Cabinet the Prime Minister urged Ministers to provide a different kind of governance for Canadians, noting that such a framework required:

... close collaboration with colleagues; meaningful engagement with Opposition Members of Parliament, Parliamentary Committees and the public service; constructive dialogue with Canadians, civil society, and stakeholders, including business, organized labour, the broader public sector, and the not-for-profit and charitable sectors; and identifying ways to find solutions and avoid escalating conflicts unnecessarily (GoC, 2015).

However, in 2015 the Agricultural Minister's mandate letter proved the only instance where a minister was directed to engage in the development of a national food policy. One Parliamentarian we spoke with explained this decision by pointing out that, in 2015, the Government thought placing the national food policy closer to the point of food production would make it easier to activate and "pull the agricultural sector in... to use and exercise [its] capacity to solve some of the hunger and health issues related to food scarcity and precarity" (Adam Vaughan, interview March 8, 2020). But by 2017, Trudeau updated the Health Minister's mandate letter to include the authorization to "Work closely with the Minister of Agriculture and Agri-Food to align these regulatory initiatives with food policy" (GoC, 2017a). Oliver Anderson of the Agriculture Agri-Food Minister's Office explained that although the mandates for both Ministers are clearly distinct, both letters "stem from the same thing. They demand some kind of collaboration between our two ministries," mostly in the form of "inter-departmental consultation" (Oliver Anderson, Interview, April 30, 2020). 
Consider these efforts alongside the more narrowly conceived food and nutrition policies of Brazil ${ }^{12}$, Finland and Norway mentioned earlier. Trudeau mandated Canada's national food policy to the Minister of Agriculture - to be housed in AAFC — a department historically focused on increasing production for export and which sees food production more as an economic driver, and less as a determinant of health. Thus, Canada took a very different path from the countries discussed above by grounding its food policy in a department rooted in the productivist paradigm of high input, high output agricultural systems (Skogstad, 2012). This decision not only resulted in the inherent tensions that come with locating an aspirationally integrative policy within a line department, but also generated significant work for the AAFC. As consultations moved forward, AAFC recognized the need for much stronger coordination than they initially anticipated (Oliver Anderson, Interview, April 30, 2020).

Governmental representatives came to view the Healthy Eating Strategy (2016) as a counterpart to the FPC. Later, the revised Canada Food Guide (GoC, 2019a) also played a pivotal role in the discussion of food security, health and nutritional disparities because it shifted the Government's stance of what was 'healthy' and 'nutritious' to consume. The Harvesters Support Grant ${ }^{13}$ developed under the Nutrition North program also reflects collaborative and coordinative discussion of food security, health and nutrition across Government, though the program is not even named in the FPC.

The effects of these internal state activities remain fresh, and their impacts within broader society remain unclear. Sylvain Charlebois (2019) points out that "Agriculture and Agri-Food Canada is not a central department within the federal government. Expecting it to lead Health or Finance would be purely naïve, especially with only \$134 million to spend over five years." FSC (2019) adds: "If the food policy has cross-government accountability and measurement mechanisms that encompass income support and anti-poverty actions, there is a clear need for a more robust and coherent approach." Fortunately, our research indicates that the crossdepartmental committee which was formed to create the FPC will continue to help with its implementation (personal communication, Tom Rosser, Assistant Deputy Minister of AAFC, 2019). The seeds of a more integrative approach within the federal government may yet bear more fruit.

While a cross-departmental coordinating committee on food policy is not entirely new, ${ }^{14}$ since 2015 the interdepartmental committee on national food policy has become a well-known entity within the public service. It includes 16 federal departments and agencies, and participation occurs between various positions of senior public servant officials.

\footnotetext{
12 We deliberately include Brazil in this list because its progressive Food and Nutrition Policy does not extend across its agricultural sector including, notably, its production for export markets.

${ }^{13}$ Located under Nutrition North, this funding is called the Harvesters Support Grant. See: https://www.nutritionnorthcanada.gc.ca/eng/1586274027728/1586274048849

${ }^{14}$ Between 2010-2013, the concept of food policy remained underdeveloped but a formal inter-departmental committee of six or seven departments coordinated around the topic of food policy.
} 
Further, this body has become an important and more efficient means for the communication of food policy ideas and efforts to the Agricultural Minister's Office and from there, to the Cabinet, thus keeping food policy high on the federal policy agenda (Anonymous interview April 30, 2020).

Notwithstanding greater internal consultation among government departments as represented by the inter-departmental committee, efforts to coordinate or develop new regulatory tools to ensure that health priorities might affect what happens in agriculture, such as reducing pesticide usage, remain absent. While Health Canada makes strategic use of regulations (e.g. restrictions of trans fats, salts and sugars in processed foods), the FPC has not been designed to encourage new thinking about regulations. As Rod MacRae (2019) points out: "there is no mention of the legislative and regulatory agenda to be implemented to remove impediments to this overarching goal and to encourage changes among actors that will advance it quickly."

On the question of inter-governmental coordination with other levels of government, the development of the FPC proved a federally-driven initiative with limited communication and coordination between the federal and provincial governments. The extent to which the policy was discussed between governments occurred through the Federal-Provincial-Territorial (FPT) meetings regarding agriculture. At these meetings, federal representatives noted progress on the file allowing for optional responses from counterparts. Both Québec and British Columbia have instituted progressive food policies, but the extent to which they provided national-level input remains unclear. It appears there was also limited provincial and territorial input into the proposed national school food program, which only came to be a clear policy priority of the federal government in 2019 via Budget 2019 and the FPC. However, since June 2019, the consideration and development for a national school food program has been moved from AAFC to Families, Communities and Social Development - perhaps a better fit given the department's capacity to move forward on the file.

Finally, it is worth restating that the FPC was only funded to \$134 million. Sylvain Charlebois (2019) referred to this budget as "underwhelming at less than $\$ 4$ per capita", comparing it to Québec's 2018 provincial food policy budget of \$349 million, which worked out to $\$ 40$ per capita. Further, Charlebois pointed out that Québec's approach was "very strategic, systematic and engaging as it offered specific policy goals and benchmarks" - both of which are still missing in the federal policy announcements of 2019.

\section{Ecological sustainability for health?}

Next, we reflect on how, over the course of its development, the FPC progressed in framing the interrelationship between food, health and environment. For example, as consultations began, the environment theme was summarized as "conserving our soil, water and air" (consultation document on file with authors). 
However, the What We Heard report (2018b) noted:

Consultation participants expressed that the preservation of agricultural land and biodiversity were key elements missing in the title of the theme and wanted to see more emphasis on both. The lack of reference to biodiversity was a concern for Indigenous participants, and, in particular, among those who noted its importance for hunting and harvesting related to country/traditional food production. (p.23)

Responding to such concerns, the final policy document (2019d) now includes, under the 'sustainability' theme: "Fostering protection and conservation of the environment, including support for the adoption of practices and technologies that contribute to clean air and water, soil health, biodiversity, sustainable use of resources (e.g. greenhouse gas emissions, energy, farm inputs, and water) and climate change mitigation and adaptation" (p.12). Further, "sustainable food practices" are identified as one of six key outcomes the policy seeks to achieve-defined as "improvements in the state of the Canadian environment through the use of practices along the food value chain that reduce environmental impact and that improve the climate resilience of the Canadian food system" (p.7)

The FPC includes an explicit environmental focus in its food waste reduction challenge. Responding to the fact that over half of Canada's food supply is lost, in November 2020, the federal government provided the details for a contest that will award up to $\$ 10.8$ million to innovators for developing new business models that significantly "prevent or divert food waste at any point from farm to plate" (GoC, 2020c). To ensure that innovations get developed, the contest will use a staged approach, with expert feedback along the way, to help innovators deploy their proposed solutions. This contest as a clever step forward on a vexing policy issue, and we hope it will yield fruit. At the same time, relying on a contest as policy instrument reveals just how isolated this first iteration of the FPC is within the broader framework of government policies and guidance related to food and agriculture.

While the initiative described above represents progress, the FPC was an opportunity to employ a range of tools, including targeted investments and disincentives, to encourage forms of production and value chains which are both more environmentally sustainable and nutritious. We could have seen a target for expanding organic farming in Canada, for example, recognizing this as an important path towards sustainability. This was the direction taken in the European Commissions' Farm to Fork Strategy (2020) which targets $25 \%$ of agricultural land in organic farming by 2030 , as part of its plan to make the EU climate-neutral by 2050 . However, such tools and targets are entirely absent from the policy. 
Charlebois (2019) notes a similar absence of targets and incentives around plant-based diets, pointing out that the policy...

\begin{abstract}
... does not suggest that Canada should focus on certain commodities more than others, given what lies ahead with produce and vegetable proteins. Canada's new food guide recommends a dietary regimen that is out of reach for Canada's agriculture. Growth is essential in some areas like horticulture and pulses, particularly, and no specific provisions are made for these sectors. (para. 5)
\end{abstract}

Limited policy action on this front belies the limited role that AAFC currently plays on primarily health-related policies. This is a systemic flaw to which we return below.

Another way that the FPC could serve both environmental and health goals is through its 'Buy Canadian' promotion campaign, which received \$25 million in the FPC budget announcement (GoC, 2019a). In principle, environmental benefits could come from encouraging Canadians to support local food producers (Andrée, 2006). And encouraging Canada's brand in export markets could deliver environmental, economic and health benefits (Andrée et al. 2014). However, the oligopolistic structure of the global food system tends to encourage unsustainable models of production and distribution (Clapp, 2020) unless value chains are held to account to genuine sustainability standards (Friedmann, 2005). Even when such standards exist, like in the fair-trade market, pressures to relax them are pervasive (Fridell, 2014). We see potential in the National Index on Agri-Food Performance initiative currently underway to link the development of Canada's Brand to robust sustainability metrics (McInnes, 2020), but it is too soon to say if the results of this initiative, when linked to 'Buy Canadian' campaigns as its corporate partners intend, will result in substantial environmental or health dividends.

\title{
Food security and the right to food?
}

In late 2016, the government identified four central "potential themes" for a Canadian national food policy:

"Food Security", "Health", "Environment" and "Sustainable Growth of the Agriculture and Food Sector" (Meredith, 2016). This four-part framework posed certain limitations, as divisions among themes could preclude acting on cross-cutting solutions. For example, encouraging the substitution of plant-based protein for animal protein could address an array of health, environmental and economic goals. Nonetheless, of the four themes, "Food Security" as a concept is almost absent from the final policy. The FPC (2019d) only names food security twice: once referring to the type of organizations that gave input into the policy, and once referring to the four actions designed "to address key gaps" (p. 9). That action is entitled "Support Food Security in Northern and Indigenous Communities," which the budget funds for $\$ 15 \mathrm{M}$ over the period 2019-2024 (GoC 2019d, p. 9). 
While this new program is welcome, Canada-wide food security is not identified as a priority outcome - especially problematic given the racialized ways in which food insecurity is perpetuated. Contradicting the absence of an ambitious Canada-wide goal to address food insecurity, the FPC does seek to align progress indicators with the UN's Sustainable Development Goals (SDGs) (GoC 2019c, p.13; see also Ballamingie et al., 2020). By signing on to the SDGs, Canada has committed to eliminating hunger by 2030, with the Minister of Families, Communities and Social Development leading this file as of the 2019 election (GoC, 2021a, February 17). Food Secure Canada caught the significance immediately, arguing (FSC, 2019)

There are references to food security scattered through the Policy yet they are not pulled together as a specific priority outcome. If the food policy has cross-government accountability and measurement mechanisms that encompass income support and anti-poverty actions, there is a clear need for a more robust and coherent approach. (para 23)

The diminutive status of food security in final documents may be partly explained by how the discussion on this issue evolved from 2016 to 2019. Initially, food security was coupled with concepts like the "affordability" of food (Meredith, 2016). However, during the consultations, the government heard from various quarters that in most communities, food security must be understood not in terms of "affordability" but more in terms of income security. The What We Heard report of 2018 spelled this out clearly, with a subsection entitled 'addressing food security as an income issue' (GoC 2018c, p.13). It states that "a wide range of participants" called for policy solutions that "address income disparities and poverty" as root causes of food insecurity. It further notes that while affordability of food remains a high priority, especially in isolated, northern communities, many deemed the term inappropriate, "instead focusing on ensuring access to and availability of safe and nutritious food" (GoC, 2018c, p.13). In our view, Tarasuk and the PROOF Food Insecurity Policy Research network deserve credit for reframing food security as symptomatic of income insecurity - fueling a growing movement in Canada that supports the notion of a basic income guarantees (Drachner \& Tarasuk, 2018). However, reframing food security as an income issue took it squarely out of the wheelhouse of AAFC, once again revealing a structural problem with this policy. While the FPC was ostensibly released by the government of Canada as a whole, the policy mainly includes actions that AAFC can execute unilaterally, and income security is not among these. Paul Taylor of FoodShare in Toronto (as quoted in Hui, 2019) sums up what the policy does to address food security bluntly: "we know the issue around food insecurity is largely around income... This [policy] is not how we respond to a crisis like food insecurity" (para.17). Again, because black, Indigenous, and people of colour (BIPOC) are subjected to economic inequalities, addressing income security has important implications for racial justice.

And what of the Right to Food? Unfortunately, this concept followed a similar trajectory to food security. 
The Right to Food was invoked repeatedly during consultations but remains absent from the final policy. Among others, the ad hoc Working Group on the Right to Food noted at the National Food Summit in June 2017 that the right to food was absent, arguing that the food policy needed to consider De Schutter's (2012) mission to Canada report (Nadia Lambek, Interview, April 22, 2020). Shortly thereafter, in September 2017, the House of Commons Standing Committee on AAFC began a study on food policy in parallel to governmental consultations on the proposed FPC.

This committee's report recommended attention to the Right to Food, and the government's response (GoC 2018a) stated that it agreed with this recognition 'in principle' and would seek to align its policy accordingly. The What We Heard (GoC 2018a) report also gave a full paragraph to the Right to Food, stating that many participants "shared the view that a policy founded on the recognition of the right to food for all residents and communities within Canada would commit the nation to a long-term goal of ending, and not merely reducing, food insecurity" (p, 14). Following this report, however, the Right to Food disappears from the food policy process. Dr. Charles Levkoe explains this gap by noting that introducing the Right to Food in Canada's governance around agriculture and agri-food policy means fundamentally shifting the pathdependent trajectory of AAFC (Charles Levkoe, Interview May 4, 2020). We would add that the authority to invoke the Right to Food would require considerable leadership from outside AAFC, and the FPC development process was simply not structured that way.

\section{Meaningful consultation towards Indigenous food self-determination?}

Next, we consider whether the FPC furthers the goal of Indigenous food self-determination. We begin with reflections on the FPC consultation process. Indigenous Peoples and their allies raised many concerns regarding the consultation process - related to both substance and interface. During the self-led Assembly of First Nations (AFN) engagement session in October 2017, participants characterized Canada's consultation process as not inclusive enough for meaningful engagement with First Nations. Although the Government supported and funded self-led processes, not all national organizations could participate. Further, of the six regional engagement sessions that took place across Canada, only one of these reached an Indigenous audience in participation and subject matter, and even this one could not address issues relevant to specific First Nations. The session in Yellowknife, Northwest Territories, although attended by the Agriculture Minister, provided neither the means to discuss food-related issues of northern Yukon, nor the space to discuss Aboriginal Title and rights as they related to food (Levi, 2017). Collectively, aside from First Nations, Inuit and Métis, no other population in Canada holds these unique rights. The abbreviated consultations failed to afford the time and space necessary for Indigenous, state and other stakeholders to unpack these complex dynamics. 
Regarding policy substance and program development, AAFC worked with Indigenous and Northern Affairs to develop relevant food policy and programs alongside the FPC, but these efforts were never seen as integral to the food policy itself. Specifically, AAFC helped to develop the Harvesters Support Grant (while revising the Nutrition North subsidies program), but since this work fell beyond the scope of its departmental authority and responsibility, it was not mentioned in the national food policy documents (led by AAFC). Similarly, in 2016, Nutrition North was already being revamped, but this process was also seen by internal government actors to lie outside the FPC consultation process (Oliver Anderson, Interview, April 30, 2020). In 2016, Nutrition North expanded to include an additional 37 isolated northern communities to help more families access affordable and healthy food (GoC, 2016). The fact that these efforts - critical to questions of Indigenous food security and health — were perceived to lay outside the food policymaking process raises further questions about how 'integrated' the intragovernmental process around food policy really was.

And what do we find within the FPC announced in 2019? The government gave "strong Indigenous food systems" ... "co-developed in partnership with Indigenous communities and organizations" a high profile - as one of only six major outcomes articulated for FPC success (GoC 2019d, p.7). Further, the government situated the policy in the context of reconciliation and self-determination: "The FPC will help advance the Government of Canada's commitment to Reconciliation with Indigenous Peoples, build new relationships based on respect and partnership, and support strong and prosperous First Nations, Inuit and Métis food systems - as defined by communities themselves" (Goc 2019d, p.7) However, despite this statement, the government provided only modest new funding ( $\$ 15$ million) for Northern and Indigenous communities.

In sum, some promising elements related to Indigenous food systems exist in the FPC, which reflect this government's stated commitment to reconciliation. However, a questionable consultation process demands more substantive progress in this space. Given the stated goal of an integrated federal government approach, the omission of links to other key programs and efforts-like NNC, however, remains problematic (Galloway, 2017).

\section{Healthy food environments?}

Government named "Improved food-related health outcomes" as a key measure against which the policy's success should be evaluated (GoC, 2019d). They further specified the goal of "Improved health status of Canadians related to food consumption and reduced burden of dietrelated disease, particularly among groups at higher risk of food insecurity" (GoC, 2019d, p.6) Further, the FPC 'outcomes' section identified: "Vibrant communities: Improved community capacity and resilience to food-related challenges". Moreover, the government noted the complementarity of the healthy eating guidelines in their revised Canada Food Guide as an 
initiative with which the FPC aligns (GoC 2019a). Notably, progress on another key effort, frontof-pack labelling of salt, sugar and fat remained stalled (and unnamed).

The policy does include two key new programs funded in 2019: a \$50-million Local Food Infrastructure Fund to support community-led projects such as greenhouses, food banks and farmers' markets; and \$15-million toward addressing food insecurity in northern and isolated communities by subsidizing the high cost of hunting, for example. Various civil society organizations welcomed these investments ${ }^{15}$ _ expected to encourage health-promoting food environments to some extent. However, they also cautioned that funding and vision remain limited. And, as noted above, many had advocated strongly for a national school food program, but government only signaled its commitment to work on this with the provinces and territories raising questions about how (and if) this will be developed. Further, notwithstanding attention to food issues in Northern and Indigenous communities, there is no explicit mention of health equity as an issue that needs to be thought through in any new efforts to address nutrition-related food issues in Canada.

\section{Meaningful stakeholder and public engagement?}

In addressing stakeholder engagement, this section also tackles the issue of indicators and accountability, as the government policy combines them together through the new Canadian Food Policy Advisory Council.

One of the priority outcomes named in FPC is "Increased connections within food systems: Increased governance spaces and partnerships that connect multiple sectors and actors across the food system" (GoC, 2019e, p.6). We can see this was already occurring within the Government, even before 2015, but the combination of mandating collaboration of stakeholders and the development of a FPC appear to have a heavy influence in moving Canada towards a more integrated, partnership-based approach to food policy making.

The Canadian Food Policy Advisory Council (CFPAC) represents the key mechanism announced for increased coordination. Its role is described as follows: “... to support the implementation and evolution of the policy, build consensus and trust among food system stakeholders, provide input on the specific and measurable targets, and contribute to evidencebased decision making in order to reach the policy's outcomes." Rosser, Assistant Deputy Minister of AAFC, notes that a critical first step will be to develop metrics for monitoring progress on food policy in Canada in relation to the SDGs (Tom Rosser, personal communication, 2019). This governance mechanisms clearly builds on recommendations made by the ad hoc Working Group on Food Policy Governance.

\footnotetext{
${ }^{15}$ See, for example: Community Food Centers Canada (https://cfccanada.ca/en/News-Events/LatestNews/Announcements/Everyone-at-the-Table-the-federal-government-anno) and National Farmers Union (https://www.nfu.ca/national-food-policy-must-be-seen-as-a-base-for-further-action/)
} 
Why this level of responsiveness to an 'ad hoc' working group? As Rosser asserted in a panel on food policy governance at the Food Secure Canada conference in November of 2018: "When everyone agrees that governance is critical, it becomes a very difficult idea to ignore."

The CFPAC may be a real win for an ecological public health approach to food policy in Canada, and novel in relation to our international comparators (with stronger industry engagement).

The many organizations that lobbied for participation moving forward received the announcement favourably. For example, USC (now SeedChange) notes: "This is a chance for Canada to build on inclusive governance mechanisms already established, from food policy councils at the city level, to the Committee for World Food Security at the international level" (USC 2019, para.9). However, as noted, the CSM to the CFS includes specific lines of accountability. Organizations are nominated to represent their sectors through a complex process to ensure accountability (Anderson, 2019). Canada opted for a looser nomination process (encouraging nominees to get letters of support from diverse constituencies). A full year after it was announced, we have yet to see the composition and mandate of the CFPAC, but we recognize that questions of who is on it, and what it will do, can make a huge difference to what the FPC becomes.

\section{Conclusion}

An emergent ecological health paradigm offers new expectations of how governments engage in the food system to protect health and the environment. Since the FPC establishes goals consistent with this paradigm, we examined it through that lens in this paper. We found many positive signs in both named 'principles' and select outcomes the policy seeks to achieve. However, many of the bigger expectations for this policy remain lacking. Are the links recognized between food, health and environment? In theory, somewhat, but no new policy directions flow from this. How is food security addressed? Minimally, and certainly not as an income-security issue. Is the right to food recognized? No, despite strong advocacy to have it included. How are Indigenous food systems addressed? We see a promising start, given this government's overall stated priority of reconciliation, but limited consultation proved troubling. Is the FPC's framework consistent with food environments research? Again, we find some promising signs (e.g., a nod towards national school food, and small amounts of funding for local food infrastructure as well as Northern and Indigenous food systems), but these are all just starting points.

Do we find intra- and inter-governmental coordination, arguably the true hallmarks of an integrative or joined-up policy? Clearly, government has taken the first steps in this regard. Entrenched interests, governmental silos and path dependency within AAFC (as identified in Andrée et al., 2018) remain major challenges, but within this context new ways of working are emerging, though it is unclear whether accountability to the FPC is a priority beyond AAFC. 
Do we find potential for evidence-based decision making? If the focus on metrics and SDGs remains, then perhaps, but funding limitations could be a real challenge. And is there collaboration with civil society and industry? We remain hopeful the Canadian Food Policy Advisory Council will facilitate this, but we have yet to see its makeup and full mandate. The FPC also leaves us with issues that deserve future examination, but which lay beyond the scope of our analysis in this paper, including the announced pilot project towards permanent residency for some migrant farm workers (GoC 2019b).

Overall, we do not yet see an integrative, systems-based approach to addressing food and nutrition-related health issues consistent with a paradigm of ecological public health, despite some progress made. The government presented its FPC as a collaborative, integrative effort, and our interviews reveal that the civil service sees it this way too. Similarly, MacRae (2019) notes: "AAFC appears to have finally recognized that the food economy should be a servant of other objectives, rather than a prime objective in itself" (para. 5). Steps forward have been made, though this new approach remains in its early days. Further, the FPC does not yet chart a path through many outstanding tensions within the food system. Examples of tensions include (among others): the simultaneous desire to bolster agricultural exports and local productive capacity for greater self-sufficiency; the contest between dominant, mainstream, conventional production and alternative, smaller-scale, and often community-based modes of production; the increasing loss of (and concentration of remaining) arable land coupled with the goal to produce more for a growing global population; and the shift in producer demographics, as Canada "consolidates farm operations", shrinking the total number of farms in Canada (while still increasing acreage), successors (young people, immigrants with agrarian backgrounds, second careerists) face significant challenges accessing land and capital (Qualman et al., 2018: P. 102).

So, what has changed? To see the institutional change that has occurred, consider the government's response to the standing committee report of just a year earlier. This response emphasized existing programs and policies that help to achieve food policy goals, such as the prenatal nutrition program and the much-critiqued Nutrition North program (Galloway, 2017), but offered few new ideas ( $\mathrm{GoC} 2018 \mathrm{a}$ ). It also relegated 'local food' to the purview of provinces and territories and emphasized reaching healthy eating goals through 'food literacy' rather than more interventionist policy approaches. Much of that report focused major industry concerns, such as streamlining approvals for new biotechnology innovation, using food policy to improve 'public trust' in Canadian food production and processing practices, and expanding exports by $34 \%$ by 2025 (GoC 2018a). From that governmental report, only two efforts became action areas in the FPC of 2019 ('make Canadian food the top choice at home and abroad' and action to reduce food waste) - alongside two other initiatives (community infrastructure and new Indigenous/northern programs) that do in fact signal a departure from earlier AAFC priorities and programming (Goc 2019d). The latter examples demonstrate that small changes are taking place in how the federal government is responding to food-related issues. 
To implement the FPC in an integrative way consistent with an ecological public health paradigm, following MacRae (2019, para. 12), government must modify existing programs to match new policy priorities, develop "new and innovative instruments" to address challenges like food insecurity, "shift its internal decision-making to make a joined-up approach a reality", and develop effective coordinating mechanisms for FPT collaboration.

Moreover, given the inevitable tensions that will arise between health, environmental, and economic priorities, strong leadership will be required to privilege the former appropriately, and procedures must be put in place to resolve such tensions. While countries such as Brazil, Finland and Norway developed parallel policies for different sectors, Canada has the potential to be a global leader in developing the first truly integrative food policy approach.

Various unanswered questions remain at top of mind. Perhaps most critically, the perspectives and lived experiences of vulnerable sub-populations must be reflected in the development and implementation of both the FPC and its governance. Will the proposed CFPAC include these voices, and how might the interplay between equity concerns and productivist agriculture yield new insights? To what extent will the CFPAC serve as one of the coordinating mechanisms that Canada clearly needs, within the federal government, and with other levels of governments, external stakeholders and the public? Will potentially critical issues that have been sidelined to date (e.g., the Right to Food, income security, Basic Income Guarantees) make their way back onto the agenda? What effects might we expect from the growing alignment between civil society and private sector actors in a CFPAC? And, how will critical environmental and social backdrops, such as climate change and loss of biodiversity, or Reconciliation and household food insecurity (Health Canada, 2014), impact the future development of the FPC? These are the questions at the fore of our research agenda moving forward.

\section{References}

ad hoc Working Group on Food Policy Governance (2017a, October 2). The case for a national food policy council. Food Secure Canada. https://foodsecurecanada.org/sites/foodsecurecanada.org/files/attached_files/the_case_for_ a_national_food_policy_council_final.pdf

ad hoc Working Group on Food Policy Governance (2017b, October 2). Letter to the Honourable Lawrence MacAulay, re: Food policy governance innovation and a national food policy council. National Food Policy Council. https://mma.prnewswire.com/media/620399/Maple_Leaf_Foods_Inc_Broad_Coalition_C alls_on_Federal_Governmen.pdf

ad hoc Working Group on the Right to Food. (2017, September 30) Ensuring the human right to a food policy for Canada. Food Secure Canada. https://foodsecurecanada.org/sites/foodsecurecanada.org/files/attached_files/right_to_food _submissions_on_a_food_policy_for_canada.pdf 
Adelson N. (2005). The embodiment of inequity: health disparities in aboriginal Canada. Can Journal of Public Health. 96 Suppl 2(Suppl 2):S45-61. doi: 10.1007/BF03403702.

Anderson, M. (2019). Comparing the effectiveness of structures for addressing hunger and food insecurity. In. P. Andrée, J.K. Clark, C.Z. Levkoe \& K. Lowitt (Eds.) Civil society and social Movements in food system governance (pp. 124-144). Routledge.

Andrée, P. (2007). Genetically modified diplomacy. Vancouver, B.C. University of British Columbia Press.

Andrée, P. (2006). And miles to go before I eat... local limitations. Alternatives, 32(3),19-21.

Andrée, P., Ayres, J., Bosia, M., \& Massicotte, M.-J. (Eds.) (2014). Globalization and food sovereignty: Global and local change in the new politics of food. University of Toronto Press.

Andrée, P., Norgang, E., Clement, C., Langille, L., \& Williams, P. (2016). Structural constraint and enablers to community food security in Nova Scotia, Canada. Journal of Hunger and Environmental Nutrition, 11(4), 456-490.

Andrée, P., Coulas, M., \& Ballamingie, P. (2018). Governance recommendations from forty years of national food policy development in Canada and beyond. Canadian Food Studies, 5(3), 6-27. https://www.doi.orge/10.15353/cfs-rcea.v5i3.283

Andrée, P., Coulas, M., \& Ballamingie, P. (2019). Canada's national food policy: The political basis for coordination and integration. In H. McLeod-Kilmurray, N. Chalifour, \& A. Lee (Eds.) Food law and policy in Canada. (pp. 13-36). Carswell Publishing (Thomson Reuters Canada).

Bacon, S. L., Campbell, N., Raine, K. D., Tsuyuki, R. T., Khan, N. A., Arango, M., \& Kaczorowski, J. (2019). Canada's new Healthy Eating Strategy: Implications for health care professionals and a call to action. Canadian Pharmacists Journal/Revue des pharmaciens du Canada. 152(3), 151-157. doi: 10.1177/1715163519834891

Ballamingie, P., Blay-Palmer, A.D., Knezevic, I., Lacerda, A.E.B., Nimmo, E.R., Stahlbrand, L., \& Ayalon, R. (2020). Integrating a food systems lens into discussions of urban resilience: Analyzing the policy environment. Journal of Agriculture, Food Systems and Community Development, 9(3), 227-243. doi: 10.5304/jafscd.2020.093.021

Barling, D., Caraher, M., \& Lang, T. (2009). Food policy: Integrating health, environment and society. Oxford University Press.

Berger Richardson, S., \& Lambek, N. (2018). Federalism and fragmentation: Addressing the possibilities of a food policy for Canada. Canadian Food Studies, 5(3), 28-48. doi: $\underline{10.15353 / \mathrm{cfs}-\mathrm{rcea} . v 5 i 3.281}$

Blueprint for a National Food Strategy. (2017, February). Centre for Agriculture and Food Systems at Vermont Law School and the Harvard Law School Food Law and Policy Clinic. https://foodstrategyblueprint.org/wp-content/uploads/2020/10/Food-Strategy-Blueprint.pdf

Bundy, D. A., Drake, L. J., \& Burbano, C. (2012). School food, politics and child health. Public Health Nutrition, 16(06), 1012-1019. 
Canadian Agri-Food Trade Alliance (CAFTA). (2021). Agri-food exports. https://cafta.org/agrifood-exports/

Canadian Biotechnology Action Network (CBAN). (2020, December). Pesticides. Canadian Biotechnology Action Network. https://cban.ca/gmos/issues/pesticides/

Charlebois, S. (2019, June 21). Canada's first food policy is pointless and underwhelming. Ottawa Citizen. https://ottawacitizen.com/opinion/columnists/charlebois-canadas-firstfood-policy-is-pointless-and-underwhelming/

Clapp, J. (2020). Food ( $3^{\text {rd }}$ edition). Polity Press.

Community Food Centres Canada (CFCC). (2019, June 17). Everyone at the table: The federal government announces a Food Policy for Canada. https://cfccanada.ca/en/NewsEvents/Latest-News/Announcements/Everyone-at-the-Table-the-federal-government-anno

Coté, C. (2016). "Indigenizing” food sovereignty. Revitalizing Indigenous food practices and ecological knowledges in Canada and the United States. Humanities, 5(3), 57. doi: $\underline{10.3390 / \mathrm{h} 5030057}$

Dachener, N., \& Tarasuk, V. (2018). Tackling household food insecurity: An essential goal of a national food policy. Special issue: Building an integrated food policy for Canada.

Canadian Food Studies, 5(3). doi: 10.15353/cfs-rcea.v5i3.278

De Schutter, O. (2012, December 24). Mission to Canada: Report of the special rapporteur on the right to food. Human Rights Council. (Reference No.: GE.1218956). https://www.ohchr.org/Documents/HRBodies/HRCouncil/RegularSession/Session22/AHR C2250Add.1_English.PDF

Engler-Stringer R, Le H, Gerrard A, Muhajarine N. (2014). The community and consumer food environment and children's diet: a systematic review. BMC Public Health. 29(14): 522-. doi: 10.1186/1471-2458-14-522.

European Commission. (2020, September 4). European green deal: Commission prepares new initiatives to boost the organic farming sector. 4 September. https://ec.europa.eu/commission/presscorner/detail/en/IP_20_1548

Fischer, F., Torgerson, D., Durnova, A., \& Orsini, M. (2015). Handbook of critical policy studies. Edgar Elgar Publishing.

Food and Drug Act. R.S.C., 1985, c. F-27 https://laws-lois.justice.gc.ca/eng/acts/f27/fulltext.html

Food: Locally Embedded, Globally Engaged (FLEdGE). (2016). Good food principles. https://fledgeresearch.ca/good-food-principles/

Food Secure Canada (FSC). (n.d.). Food sovereignty. Food Secure Canada. https://foodsecurecanada.org/who-we-are/what-foodsovereignty\#: :text=\%22Food\%20Sovereignty \%20is\%20the\%20right,injustice $\% 20 \mathrm{in} \% 20 \mathrm{t}$ he\%20food\%20system.

Food Secure Canada (FSC). (2018, September 7). Government releases "What We Heard" report on food policy: What does it mean? Food Secure Canada. 
https://foodsecurecanada.org/resources-news/news-media/orchestrating-better-foodsystem-hearing-canadians-food-policy

Food Secure Canada (FSC). (2019). The Launch of the First 'Food Policy for Canada Everyone at the Table. Food Secure Canada. https://foodsecurecanada.org/first-nationalfood-policy-for-canada

Foucault, M. (1991). On governmentality. In G. Burchell, C. Gordon, \& P. Miller (Eds.) The Foucault effect (pp. 87-104). University of Chicago Press.

Fridell, G. (2014). Fair trade slippages and Vietnam gaps: the ideological fantasies of fair trade coffee. Third World Quarterly, 35(7), 1179-1194.

Friedmann, H. (2005). From colonialism to green capitalism: Social movements and emergence of food regimes. In F. Buttel \& P. McMichael (Eds.), New Directions in the Sociology of Global Development (pp. 227-264.) Emerald Group Publishing Limited.

Galloway, T. (2017). Canada's Northern Food Subsidy Nutrition North Canada: A Comprehensive Program Evaluation. International Journal of Circumpolar Health, 76(1), 1-19. doi: 10.1080/22423982.2017.1279451

Gooch, M., Bucknell, D., LaPlain, D., Dent, B., Whitehead, P., Felfel, A., Nikkel, L., \& Maguire, M. (2019, January 17). The avoidable crisis of food waste: Technical report. Value Chain Management International and Second Harvest. https://secondharvest.ca/wpcontent/uploads/2019/01/Avoidable-Crisis-of-Food-Waste-Technical-Report-January-172019.pdf

Government of Canada (GoC). (2012, July 25). Household food insecurity in Canada in 20072008: Key statistics and graphics. http://www.hc-sc.gc.ca/fnan/surveill/nutrition/commun/insecurit/key-stats-cles-2007-2008-eng.php\#a.

Government of Canada (GoC). (2013). [Archived]. Canadian Health Measures Survey - Select health indicators of First Nations people living off reserve, Métis and Inuit. Statistics Canada. Ottawa, Ontario. (Reference no. 82-624-X). https://www150.statcan.gc.ca/n1/pub/82-624-x/2013001/article/11763-eng.htm

Government of Canada (GoC). (2015, November 12). [Archived]. Minister of Agriculture and Agri-food mandate letter. https://pm.gc.ca/en/mandate-letters/2015/11/12/archivedminister-agriculture-and-agri-food-mandate-letter

Government of Canada (GoC). (2016). Healthy eating strategy. Health Canada. Ottawa, Ontario. (Cat.: H164-196/2016E-PDF). https://www.canada.ca/content/dam/canada/healthcanada/migration/publications/eating-nutrition/healthy-eating-strategy-canada-strategiesaine-alimentation/alt/pub-eng.pdf

Government of Canada (GoC). (2017a, October 4). [Archived] Minister of Health mandate letter. https://pm.gc.ca/en/mandate-letters/2017/10/04/archived-minister-health-mandate-letter

Government of Canada (GoC). (2017b, December). Tenth report of the Standing Committee on Agriculture and Agri-Food: A food policy for Canada. https://www.ourcommons.ca/Content/Committee/421/AGRI/Reports/RP9324012/agrirp10/ agrirp10-e.pdf 
Government of Canada (GoC). (2018a). Opportunity for All: Canada's First Poverty Reduction Strategy. Employment and Social Development Canada. Ottawa, Ontario. (Cat. No.: Em12-48/2018E-PDF). https://www.canada.ca/content/dam/canada/employment-socialdevelopment/programs/poverty-reduction/reports/poverty-reduction-strategy-report-EN.pdf

Government of Canada (GoC). (2018b, March 29). Government Response to the Tenth Report of the Standing Committee on Agriculture and Agri-Food entitled: A Food Policy for Canada. Minister of Agriculture and Agri-Food, Ottawa, Ontario. (Quote: 238542). https://www.ourcommons.ca/content/Committee/421/AGRI/GovResponse/RP9757009/421 _AGRI_Rpt10_GR/421_AGRI_Rpt10_GR-e.pdf

Government of Canada (GoC). (2018c, September). What we heard: Consultations on a food policy for Canada. Agriculture and Agri-food Canada. Ottawa, Ontario. (Cat.: A22609/2018E-PDF). https://www.canada.ca/content/dam/aafc-aac/documents/20181025en.pdf

Government of Canada (GoC). (2019a, January). Canada's Food Guide. Health Canada. Ottawa, Ontario. (Cat.: H164-257/1-2019E). https://food-guide.canada.ca/en/

Government of Canada (GoC). (2019b, March 29). Budget 2019. Finance Canada. Ottawa, Ontario. (Cat.: F1-23/3E-PDF). https://www.budget.gc.ca/2019/docs/plan/budget-2019en.pdf

Government of Canada (GoC), (2019c, June). Taking Stock: Food Waste and Reduction in Canada. Environment and Climate Change Canada. Ottawa, ON. (Cat. No.: En4364/2019E-PDF). https://www.canada.ca/en/environment-climatechange/services/managing-reducing-waste/food-loss-waste/taking-stock.html

Government of Canada (GoC). (2019d, June 17). "Everyone at the Table!" Government of Canada announces the first-ever Food Policy for Canada. https://www.canada.ca/en/agriculture-agri-food/news/2019/06/everyone-at-the-tablegovernment-of-canada-announces-the-first-ever-food-policy-for-canada.html

Government of Canada (GoC). (2019e, June 17). Food Policy for Canada: Everyone at the Table. Agriculture and Agri-food Canada. Ottawa, Ontario. (Cat.: A22-628/2019E-PDF; AAFC number: 12969E). https://agriculture.canada.ca/sites/default/files/legacy/pack/pdf/fpc_20190614-en.pdf

Government of Canada (GoC). (2020a, March 8). Provinces and territories. https://www.canada.ca/en/intergovernmental-affairs/services/provinces-territories.html

Government of Canada (GoC). (2020b, August 25). Self-government. Crown-Indigenous Relations and Northern Affairs Canada. https://www.rcaanccirnac.gc.ca/eng/1100100032275/1529354547314

Government of Canada. (2020c, November 18). Nutrition North Canada. https://www.nutritionnorthcanada.gc.ca/eng/1415385762263/1415385790537

Government of Canada (GoC). (2020d, November 19). Government of Canada launches Food Waste Reduction Challenge. https://www.canada.ca/en/agriculture-agrifood/news/2020/11/government-of-canada-launches-food-waste-reduction-challenge.html 
Government of Canada (G0C). (2021a, February 17, 2021). Government of Canada launches is 2030 Agenda National Strategy. https:/www.canada.ca/en/employment-socialdevelopment/news/2021/02/canada-launches-its-2030-agenda-national-strategy.html

Government of Canada (GoC). (2021b, April 15). Greenhouse gas emissions. https://www.canada.ca/en/environment-climate-change/services/environmentalindicators/greenhouse-gas-emissions.html

Government of Canada (GoC). (2021c, May 6). Twenty years of diabetes surveillance using the Canadian Chronic Disease Surveillance System. https://www.canada.ca/en/publichealth/services/publications/diseases-conditions/20-years-diabetes-surveillance.html

Hernandez, K., Engler-Stringer, R., Kirk, S., Wittman, H., \& McNicholl, S. (2018). The case for a Canadian national school food program. Canadian Food Studies/La Revue Canadienne Des Études Sur L'alimentation, 5(3), 208-229. doi:15353/cfs-rcea.v5i3.260

Howard, A., \& Brichta, J. (2013). [Archived] What's to eat? Improving food literacy in Canada. Ottawa: Conference Board of Canada. https://www.conferenceboard.ca/elibrary/abstract.aspx?did=5727

Hui, A. (2019, June 17). Liberals announce national food policy with \$134-million pledge to improve access. Globe and Mail. https://www.theglobeandmail.com/canada/articleliberals-announce-national-food-policy-with-134-million-pledge-to/

International Panel of Experts on Sustainable Food Systems (IPES-Food). (2016). From uniformity to diversity: A paradigm shift from industrial agriculture to diversified agroecological systems. http://www.ipesfood.org/_img/upload/files/UniformityToDiversity_FULL.pdf

Inuit Tapiriit Kanatami (ITK). (2017, November 20). An Inuit specific approach to Canadian food policy. https://www.itk.ca/wp-content/uploads/2019/01/ITK_Food-Policy-Report.pdf

Jindra, I. (2016). First world hunger revisited: Food charity or the right to food? Journal of Social Work, 16(6), 758-760. doi: 10.1177/1468017316663720

Johnson, K. (2019). Budget 2019: Canada gets a national food policy. iPolitics. https://ipolitics.ca/2019/03/19/budget-2019-canada-gets-a-national-food-policy/

Kuhnlein, H. (2013). What food system intervention strategies and evaluation indicators are successful with Indigenous Peoples? In Food and Agricultural Organization (Ed.), Indigenous Peoples' food systems and well-being: Interventions and policies for healthy communities (pp.237-256). http://www.fao.org/3/i3144e/i3144e.pdf

Krutt, C. (2019, August 21). Pulse Canada Receives Government Funding. Steinbach online.com. https://steinbachonline.com/ag-news/agriculture-news-mb/pulse-canadareceives-government-funding

Kepkiewicz, L., \& Rotz, S. (2018). Toward anti-colonial food policy in Canada? (Im)possibilities within the settler state. Canadian Food Studies / La Revue Canadienne Des études Sur l'alimentation, 5(2), 13-24. doi: 10.15353/cfs-rcea.v5i2.202

La Via Campesina. (2003, January 15). Food sovereignty. https://viacampesina.org/en/what-arewe-fighting-for/food-sovereignty-and-trade/key-documents-food-sovereignty/ 
Lang, T. (2009). Reshaping the food system for ecological public health. Journal of Hunger \& Environmental Nutrition, 4, 315-335.

Lang, T., \& G. Rayner. (2012). Ecological public health: The 21st century's big idea? BMJ 345:e5466 doi: 10.1136/bmj.e5466

Lang, T., \& Barling, B. (2012). Food security and food sustainability: Reformulating the debate. Geographical Journal, 178(4) 313-326. doi: 10.1111/j.1475-4959.2012.00480.x

Leão, M., \& Maluf, R.S. (2013). Effective public policies and active citizenship: Brazil's experience of building a food and nutrition security system [English translation]. https://www-cdn.oxfam.org/s3fs-public/file_attachments/rr-brazil-experience-foodnutrition-security-190214-en_3.pdf

Levi, E. (2017). Assembly of First Nations meeting report (draft): A national First Nations food policy information session.

Levkoe, C., \& Blay-Palmer, A. (2018). Food Counts: Food systems report cards, food sovereignty and the politics of indicators. Canadian Food Studies / La Revue Canadienne Des Études Sur L'alimentation, 5(3), 49-75. doi: 10.15353/cfs-rcea.v5i3.277

Luppens, L., \& Power, E. (2018). Aboriginal isn't just about what was before, it's what's happening now: Perspectives of Indigenous Peoples on the foods in their contemporary diets. Canadian Food Studies/La Revue Canadienne Des études Sur l'alimentation 5(2):142-61. https://doi.org/10.15353/cfs-rcea.v5i2.219.

MacRae, R. (2019, June 2019). Two pieces added to national food policy: many parts still missing. https://foodpolicyforcanada.info.yorku.ca/2019/06/two-pieces-added-to-nationalfood-policy-many-parts-still-missing/

MacRae, R., \& Winfield, M. (2016). A little regulatory pluralism with your counter-hegemonic advocacy? Blending analytical frames to construct joined-up food policy in Canada. Canadian Food Studies/La Revue Canadienne Des Études Sur L'alimentation, 3(1), 140194.

Mah, C., Cook, B., Rideout, K., \& Minaker, L. (2016). Policy options for healthier retail food environments in city-regions. Canadian Journal of Public Health, 107(Suppl 1), eS64eS67.

Mah, C., Hasdell, R., Minaker, L., Soo, S., Cook, B., \& Demaio, A. (2018). Entrepreneurialism and health-promoting retail food environments in Canadian city-regions. Health Promotion International, 33(6), 1055-1065. doi:10.1093/heapro/dax049

Martin, S. J., \& Andrée, P. (2017). Putting food sovereignty to work: Civil society governmentalities and Canada's People's Food Policy Project (2008-2011). Journal of Civil Society, 13(4), 374 391. doi:10.1080/17448689.2017.1355034

Martorell, H., \& Abergel, E. (2018). Building joined-up agricultural policies: Lessons from Québec. Canadian Food Studies / La Revue Canadienne Des études Sur L'alimentation, 5(3), 259-265. doi 10.15353/cfs-rcea.v5i3.322 
Martorell, H., \& Andrée, P. (2018). The commoning of food governance in Canada: Lessons for a national food policy. Routledge handbook of food as a commons. Jose Luis Vivero Pol, Tomaso Ferrando, Olivier de Schutter \& Ugo Mattei, (Eds.). pp. 266-280. UK: Routledge. doi: 10.4324/9781315161495-17

McInnes, D. (2020, October). Agri-Food Sustainability Targets: A Selected Overview [Report created for Canadian Produce Marketing Association]. https://cpma.ca/docs/defaultsource/industry/sustainability/report-agri-food-sustainability-targets-oct-2020.pdf

McIntyre, L., Patterson, P., \& Mah, C. (2018). A framing analysis of Canadian household food insecurity policy illustrates co-construction of an intractable problem, Critical Policy Studies, 12(2), 149-168, doi: 10.1080/19460171.2016.1253491

Meredith, G. (2016, October 14). Approach to food policy. [Slides presented at Food Secure Canada conference on behalf of Agriculture and Agri-Food Canada]. Resetting the table: Food Secure Canada $9^{\text {th }}$ national assembly, Ryerson University, Toronto, Ontario. (on file with authors).

Milio, N. (1991). Toward healthy longevity: Lessons in food and nutrition policy development from Finland and Norway. Scandinavian Journal of Social Medicine, 19, 209-217.

Ministry of Health of Brazil. (2013) National Food and Nutrition Policy. (Cat.: CDU 613.2; OS 2013/0018).

http://189.28.128.100/dab/docs/portaldab/publicacoes/national_food_nutrition_policy.pdf.

Mozzaffarian, D., Angell, S.Y., Lang, T. \& Riviera, J. Y. (2018). Role of government policy in nutrition-barriers to and opportunities for healthier eating. BMJ, 361,k2426. doi: $\underline{10.1136 / \mathrm{bmj} . \mathrm{k} 2426}$

Mulderrig, J., Montessori, N.M., \& Farrelly, M. (2019). Introducing critical policy discourse analysis. In N. M. Montessori, J. Mulderrig \& M. Farrelly. (Eds.) Critical policy discourse analysis (pp.1-22). Edward Elgar Publishing.

National Housing Strategy Act. S.C. 2019, c. 29, s. 313. https://lawslois.justice.gc.ca/eng/acts/N-11.2/FullText.html

Native Women's Association of Canada (NWAC). (2018, May). Food Policy: The Native Women's Association of Canada engagement results. https://www.nwac.ca/wpcontent/uploads/2018/06/NWAC_Food_Policy_Final_Report_May_2018.pdf

Nelson, C., Levkoe, C., \& Kakegamic, R. (2018). The need for contextual, place-based food policies: Lessons from Northwestern Ontario. Canadian Food Studies / La Revue Canadienne Des études Sur L'alimentation, 5(3), 266-272. doi.10.15353/cfs-rcea.v5i3.327

Norum, K., Bjørneboe, G-E. A., Oshaug, A., Botten, G., \& Johansson, L. (2005). Nutrition and Food Policy in Norway. In Bendich A. \& Deckelbaum R.J. (Eds.) Preventive Nutrition. Nutrition and Health (pp.735-751). Humana Press. doi: 10.1007/978-1-59259-880-9_29

Organization for Economic Cooperation and Development (OECD). (2021). The agricultural policy environment in Norway. https://www.oecd-ilibrary.org/sites/da42a3d4en/index.html?itemId=/content/component/da42a3d4-en 
Pesticide Action Network (PAN) North America. (2020). Human health harms. http://www.panna.org/pesticide-problem/human-health-harms

Pausé, C. (2019, October 14). Changing the terminology to 'people with obesity' won't reduce stigma against fat people. The Conversation. https://theconversation.com/changing-theterminology-to-people-with-obesity-wont-reduce-stigma-against-fat-people-124266

Pest Control Products Act. S.C. 2002, c. 28. https://laws-lois.justice.gc.ca/eng/acts/p-9.01/

Pietinen, P., Männistö, S., Valsta, L. \& Sarlio-Lähteenkorva, S. (2010). Nutrition policy in Finland. Public health nutrition. 13. 901-6. doi:10.1017/S1368980010001072.

PROOF. (2016a). Fact Sheet: Children in food insecure households.https://proof.utoronto.ca/wpcontent/uploads/2016/07/children-food-insecurity-factsheet.pdf

PROOF. (2016b). Fact Sheet: Monitoring Food Insecurity in Canada. https://proof.utoronto.ca/wp-content/uploads/2016/06/monitoring-factsheet.pdf

Qualman, D., Akram-Lodhi, A. H., Desmarais, A., \& Srinivasan, S. (2018). Forever young? The crisis of generational renewal on Canada's farms. Canadian Food Studies / La Revue Canadienne Des études Sur L'alimentation, 5(3), 100-127. doi: 10.15353/cfs-rcea.v5i3.284

Recine, E. (2018, November 3). Panel presentation on food policy governance: Democracy, accountability, inclusion, and complexity. Organized by P. Andrée at Resetting the Table: Food Secure Canada's 10 ${ }^{\text {th }}$ Annual Assembly. Montréal, Québec.

Riches, G., \& Silvasti, T. (2014). First world hunger revisited: Food charity or the right to food? (Second edition). Palgrave Macmillan.

Rideout, K., Riches, G., Ostry, A., Buckingham, D., \& MacRae, R. (2007). Bringing home the right to food in Canada: Challenges and possibilities for achieving food security. Public Health Nutrition, 10(6), 566-573. doi: 10.1017/S1368980007246622

Roberts, M. (2020, February 3). Black food insecurity in Canada. Institut Broadbent Institute. https://www.broadbentinstitute.ca/black_food_insecurity_in_canada

Roos, G., Lean, M., \& Anderson, A. (2002). Dietary interventions in Finland, Norway and Sweden: Nutrition policies and strategies. Journal of Human Nutrition \& Dietetics, 15, 99110.

Safe Foods for Canadians Act. S.C. 2012, c. 24. https://laws-lois.justice.gc.ca/eng/acts/S-1.1/ [Accessed June 21, 2021].

Skogstad, G. (2012). Chapter 1 Effecting Paradigm Change in the Canadian Agriculture and Food Sector: Towards a Multifunctionality Paradigm. In R. MacRea, E. Abergel,\& M. Koç (Eds.), Health and Sustainability in the Canadian Food System: Advocacy and Opportunity for Civil Society (pp. 17-38). UBC Press.

Schnitter, R. \& Berry, P. (2019). The Climate Change, Food Security and Human Health Nexus in Canada: A Framework to Protect Population Health. International Journal of Environmental Research and Public Health, 16(14), 2531-2547.

Seeds Act. R.S.C., 1985, c. S-8. https://laws-lois.justice.gc.ca/eng/acts/S-8/index.html 
Standing Committee on Agriculture and Agri-Food. (2017). A Food Policy for Canada. December. $42^{\text {nd }}$ Parliament, $1^{\text {st }}$ Session. https://www.ourcommons.ca/Content/Committee/421/AGRI/Reports/RP9324012/agrirp10/ agrirp10-e.pdf

Statistics Canada. (2019, February 25). Blood pressure and hypertension. https://www150.statcan.gc.ca/n1/pub/82-003-x/2019002/article/00002-eng.htm

Tarasuk, V., Fitzpatrick, S., \& Ward, H. (2010, April). Nutrition inequities in Canada. Applied Physiology, Nutrition and Metabolism, 35(2): 172-9. doi: 10.1139/H10-002.

Tarasuk, V., \& Mitchell, A. (2018). Household food insecurity in Canada: 2017-2018. PROOF: Food Insecurity Policy Research. https://proof.utoronto.ca/wpcontent/uploads/2020/03/Household-Food-Insecurity-in-Canada-2017-2018-FullReportpdf.pdf

The Constitution Acts 1867-1982. https://laws.justice.gc.ca/PDF/CONST_TRD.pdf

Trudeau, J. (2019, December 13). Minister of Families, Children, and Social Development Mandate Letter. https://pm.gc.ca/en/mandate-letters/2019/12/13/minister-families-childrenand-social-development-mandate-letter

Truth and Reconciliation Commission of Canada. (2015). Truth and Reconciliation Commission of Canada: Calls to Action. http://trc.ca/assets/pdf/Calls to_Action_English2.pdf

USC Canada/SeedChange. (2019, June 18). "Everyone at the table!" SeedChange reacts to the new National Food Policy. https://weseedchange.org/canada-now-has-a-national-foodpolicy-what-does-it-mean/ 